\title{
PENGARUH CURRENT RATIO, RETURN ON EQUITY, DAN DEBT TO EQUITY RATIO TERHADAP HARGA SAHAM \\ (Pada Perusahaan Konstruksi di Bursa Efek Indonesia Periode 2015-2017)
}

\author{
Bhekti Ainul Fiqih \\ bhektiainulfiqih@gmail.com \\ Universitas Ahmad Dahlan \\ Candra Vionela Merdiana \\ candra.vm@mgm.uad.ac.id \\ Universitas Ahmad Dahlan
}

\begin{abstract}
ABSTRAK
This study aims to determine the effect of Current Ratio (CR), Return On Equity (ROE) and Debt to Equity Ratio (DER) on stock prices. Current Ratio is the liquidity ratio, Return On Equity is the profitability ratio and the Debt to Equity Ratio is the Solvency ratio. The object in this study is a Construction Company listed on the Indonesia Stock Exchange (IDX). The research method in this study is a documentation method with a quantitative approach. The population used amounted to 26 companies, then the determination of the sample was determined through a purposive sampling technique. Based on predetermined2 criteria, a sample of 14 companies was obtained. The results showed that simultaneously the Current Ratio (CR), Return On Equity (ROE) and Debt to Equity Ratio (DER) variables had a significant effect on stock prices. Partially, Current Ratio (CR) has a positive but not significant effect on stock prices, while Return on Equity (ROE) has a positive and significant effect on stock prices and Debt to Equity Ratio (DER) has a negative and significant effect on stock prices. This shows that the company must maintain the value of Return On Equity (ROE) and Debt to Equity Ratio (DER).
\end{abstract}

Keyword: Current Ratio (CR), Return On Equity (ROE), Debt To Equity Ratio (DER), Stock Price.

\section{PENDAHULUAN}

Dalam menjalankan sebuah usaha membutuhkan sebuah dana. Salah satu cara yang dapat dilakukan untuk mendapatkan sebuah dana yaitu dengan berinvestasi. Berinvestasi dapat dilakukan dengan menanam saham. Saham menurut Darmadji dan Hendy (2017:19) merupakan surat berharga yang bersifat penyertaan dimana artinya ketika seseorang membeli saham suatu perusahaan, maka ia telah melakukan penyertaan modal atas perusahaan tersebut. Saham yang diperdagangkan memiliki harga yang beragam bergantung pada kualitas pada perusahaan tersebut. Harga saham menurut Wahnida (2017:14) adalah harga yang terjadi di pasar bursa pada saat tertentu yang ditentukan oleh pelaku dan ditentukan oleh permintaan dan penawaran saham yang bersangkutan di pasar modal. Indonesia saat ini ada pada era pembangunan. Dimana pada masa ini terbukti pada komitmen pemerintah yang sedang berusaha untuk meningkatkan konektivitas diseluruh indonesia. Selain itu pemerintah juga sedang berupaya membangun infrastruktur di Indonesia. Sehingga beberapa perusahaan kontruksi makan diberikan kepercayaan untuk 
mendapatkan modal dalam membiayai suatuproyek. Pada tahun 2015 - 2019 pada masa Presiden Joko Widodo ini menunjukkan kenaikan untuk anggaran biaya infrasruktur. Pemerintah mengalokasikan dana untuk infrastruktur sebesar Rp. 1.375 triliun. Angka ini menunjukkan kenaikan dibandingkan pada tahun 2005-2014. Dimana pada tahun 2005-2014 untuk anggaran belanja infrastruktur sebesar Rp. 921 triliun (Gunawan, 2018).

Pada anggaran Pendapatan dan Belanja Negara (APBN) pada tahun 2018 pemerintah menganggarkan belanja infrastruktur sebesar Rp. 410,7 triliun yang dipakai untuk berbagai pembangunan infrastruktur di seluruh Indonesia. Diantara pembangunan tersebut adalah $865 \mathrm{~km}$ jalan baru, $25 \mathrm{~km}$ jalan tol, $8.695 \mathrm{~km}$ jembatan, pembangunan bandar udara di 8 lokasi dan juga untuk pembangunan jalur kereta api. Pada tahun 2018 saham kontruksi meningkat setelah pada tahun 2017 merosot. Hal itu dikarenakan investor khawatir dalam pendanaan proyek infrastruktur tersebut. Misalnya harga saham PT PP Tbk (PTPP) merosot 35,70 persen, saham PT Wijaya Karya Tbk (WIKA) tergelincir 30,30 persen, saham PT Waskita Karya Tbk (WSKT) turun 23,33 persen, saham PT Adhi Karya Tbk (ADHI) turun 14,90 persen (Gunawan,2018).

Investor yang akan menanamkan dananya di pasar modal terlebih dahulu akan melakukan analisis. Analisis tersebut berguna agar investor yang menanamkan mampu melihat apakah dana yang di investasikan tersebut aman atau tidak. Salah satu analisis yang dapat digunakan yaitu dengan analisis kinerja keuangan. Dari analisis kinerja keuangan maka akan diketahui kinerja suatu perusahaan tersebut.

Menurut Murhadi (2013:56) ada lima analisis dalam laporan keuangan yaitu likuiditas, pengelolaan aset, pengelolaan hutang, profitabilitas dan nilai pasar.
Rasio-rasio tersebut digunakan untuk menilai kinerja keuangan suatu

perusahaan dilihat dari laporan keuangannya. Bila nilai rasio likuiditas,pengelolaan aset, pengelolaan hutang, profitabilitas dan nilai pasar baik maka artinya kinerja perusaahan tersebut baik dan begitu sebaliknya.

Current ratio menurut Husnan (1998:562) adalah rasio yang digunakanuntuk mengukur seberapa jauh aktiva lancar perusahaan bisa dipakai untuk memenuhi kewajiban lancarnya. Current ratio merupakan salah satu rasio likuiditas. Rasio ini digunakan untuk menilai kinerja suatu perusahaan dengan cara melihat dari laporan keuangannya. Semakin tinggi rasio ini menandakan semakin baik kemampuan perusahaan dalam membayar kewajiban hutang jangka pendeknya.

Menurut Murhadi (2013:89) Debt to Equity Ratio merupakan rasio yang menunnjukkan perbandingan hutang dan ekuitas perusahaan. Rasio ini untuk mengukur seberapa banyak modal sendiri yang digunakan untuk membayar seluruh hutang perusahaan. DER merupakan rasio solvabilitas dimana untuk mengetahui berapa modal sendiri yang dijadikan jaminan untuk semua hutang perusahaan. Jika semakin besar hutang maka semakin besar resiko perusahaan.

Menurut Tandeliin (2007: 240) Return On Equity (ROE) adalah rasio yang digunakan untuk menggambarkan sejauh mana perusahaan mampu menghasilkan laba bagi para pemegang saham. Return on equity merupakan salah satu rasioprofitabilitas. Salah satu keberhasilan suatu perusahaan dilihat dari seberapa banyak laba yang didapatkan. Jika suatu perusahaan menghasilkan laba tinggi maka menandakan kinerja perusahaan tersebut baik.

Penelitian ini dilakukan pada perusahaan sektor kontruksi. Dengan adanya penggenjotan pembangunan yang sedang dilakukan oleh pemerintah maka akan berdampak pada saham kontruksi. 
Kepercayaan pemerintah memberikan proyek kepada perusahaan kontruksi akan mempengaruhi kepercayaan calon investordalam menanamkan sahamnya pada perusahaan kontruksi tersebut. Calon investor akan semakin tertarik dalam menanamkan modalnya di perusahaan tersebut apabila kinerja keuangan pada perusahaan sektor kontruksi pun juga baik. Jika kinerja keuangan baik maka akan berpengaruh terhadap harga saham.

Berdasarkan Rumusan masalah yang telah dikemukakan di atas, tujuan yang ingin dicapai dari penelitian ini adalah :

1. Untuk mengetahui Current Ratio (CR) berpengaruh positif dan signifikan terhadap harga saham

2. Untuk mengetahui Return On Equity (ROE) berpengaruh positif dan signifikan terhadap harga saham

3. Untuk mengetahui Debt to Equity Ratio (DER) berpengaruh negatif dan signifikan terhadap harga saham

4. Untuk mengetahui Current Ratio (CR), Return On Equity (ROE), dan (DER) secara simultan berpengaruh terhadap harga saham

\section{REVIEW LITERATUR DAN HIPOTESIS}

\section{Harga Saham}

Saham menurut Darmadji dan Hendy (2017:19) merupakan surat berharga yang bersifat penyertaan dimana artinya ketika seseorang membeli saham suatu perusahaan, maka ia telah melakukan penyertaan modal atas perusahaan tersebut. Dengan menyertakan modal tersebut, maka pihak tersebut memiliki klaim atas pendapatan perusahaan, klaim atas asset perusahaan, dan berhak hadir dalam Rapat Umum Pemegang Saham (RUPS) Ratri (2015:31)

\section{Rasio-rasio keuangan}

Dalam laporan keuangan ada berbagai jenis rasio. Rasio memungkinkan untuk investor menganalisis laporan keuangan yang ada di suatu perusahaan. Menurut Murhadi (2013:56) analisis rasio terbagi kedalam 5 kelompok yaitu:

\section{Rasio Likuiditas}

Rasio likuiditas yaitu rasio yang menunjukkan kemampuan perusahaan dalam memnuhi liabilitas jangka pendeknya. Dalam rasio likuiditas ada 3 rasio yaitu current ratio, quick ratio, dan cash ratio. Dalam penelitian ini rasio yang digunakan adalah current ratio. Current Ratio adalah rasio yang digunakan untuk mengukur kemampuan perusahaan dalam membayar kewajiban jangka pendeknya. Current Ratio termasuk dalam rasio likuiditas. Rasio ini merupakan salah satu rasio yang digunakan untuk menilai kinerja suatu perusahaan dengan cara melihat dari laporan keuangannya. Semakin tinggi rasio ini menandakan semakin baik kemampuan perusahaan dalam membayar kewajiban hutang jangka pendeknya. Jika nilai rasio ini sangat tanggi itu menandakan bahwa perusahaan terlalu banyak menyimpan aset lancar namun jika rasio ini terlalu rendah menandakan bahwa perusahaan tidak mampu membayar tagihan-tagihan atau kewajibannya secepat mungkin. Hal tersebut mampu mempengaruhi kinerja perusahaan sehingga berpengaruhterhadap harga saham. Menurut Prastowo (2005:84) current ratio dapat dirumuskan sebagai berikut:

$$
\text { Current Ratio }=\frac{\text { Aktiva Lancar }}{\text { Hutang lancar }}
$$

\section{Rasio Pengelolaan aset}

Rasio pengelolaan aset adalah rasio yang menggambarkan efektivitas perusahaan dalam mengelola aset non kas menjadi aset kas. Rasio yang 
termasuk adalah receivables turnover ratio (RTR), average collection period $(A C P)$, inventory turnover ratio (ITR), days of inventory (DOI), payable turnover $(P T)$, average payment period (APP), total asset turnover (TATO).

\section{Rasio Pengelolaan Hutang}

Rasio pengelolaan hutang adalah rasio yang menggambarkan kemampuan perusahaan dalam mengelola dan melunasi kewajibannya. Dalam rasio ini terbagi menjadi dua kelompok yaitu rasio hutang (leverage ratio) dan solvency ratio (debt coverage ratio). Rasio hutang (leverage ratio) adalah rasio yang menggambarkan proporsi hutang terhadap aset ataupun ekuitas. Rasio hutang memiliki beberapa kategori yaitu: debt ratio (DR), debt to equity ratio (DER), dan long term debt to equity (LTDE). Solvency ratio adalah rasio yang menggambarkan kemampuan perusahaan untuk memenuhi kewajiban pokok maupun bunga. Rasio yang termasuk dalam solvency ratio adalah times interest earned ratio (TIER), debt service coverage ratio (DSCR), solvency ratio (SR) dan DEBT/EBITDA.

Dengan adanya hal tersebut akan berpengaruh terhadap harga saham. Return on equity merupakan salah satu rasio yang digunakan untuk mengukur sejauh mana kemampuan perusahaan menghasilkan laba yang dihasilkan. Semakin tinggi rasio ini semakin baik yang menandakan bahwa kinerja perusahaan baik. Menurut Husnan (2005:331) return on equity (ROE) dapat dirumuskan sebagai berikut:

\section{DER $=$ Total Hutang}

\section{Total Ekuitas}

\section{Rasio Profitabilitas}

$\begin{array}{lrr}\text { Rasio profitabilitas } & \begin{array}{r}\text { yaitu rasio } \\ \text { kemampuan }\end{array} \\ \text { yang menggambarkan } & \begin{array}{r}\text { menghasilkan } \\ \text { perusahaan }\end{array} \text { untuk } & \text { menghas } \\ \text { keuntungan. Yang termasuk dalam rasio }\end{array}$

ini adalah gross profit margin (GPM), Operating Margin (OM), net profit margin (NPM), return on equity (ROE), dan Return on Assets (ROA). Dalam penelitian ini rasio yang digunakan adalah return on equity. Menurut Tandeliin (2007: 240) Return On Equity (ROE) adalah rasio yang digunakan untuk menggambarkan sejauh mana perusahaan mampumenghasilkan laba bagi para pemegang saham. Return on equity merupakan salah satu rasio profitabilitas. Salah satu keberhasilan suatu perusahaan dilihat dari seberapa banyak laba yang didapatkan. Jika suatu perusahaan menghasilkan laba tinggi maka menandakan kinerja perusahaan tersebut baik.

Tingginya laba akan menarik investor untuk menanamkan modalnya di suatu perusahaan tersebut. Dengan adanya hal tersebut akan berpengaruh terhadap harga saham. Return on equity merupakan salah satu rasio yang digunakan untuk mengukur sejauh mana kemampuan perusahaan menghasilkan laba yang dihasilkan. Semakin tinggi rasio ini semakin baik yang menandakan bahwa kinerja perusahaan baik. Menurut Husnan (2005:331) return on equity (ROE) dapat dirumuskan sebagai berikut:

$$
\mathrm{ROE}=\frac{\text { Laba Bersih Sebelum Pajak }}{\text { Modal Sendiri }}
$$

\section{Rasio Nilai Pasar}

Rasio yang termasuk dalam rasio nilai pasar adalah earning per share (EPS), dividend payout ratio (DPR), price to earnings ratio (PER), dividend yield $(D Y)$, price to book value ratio $(P B V)$, price/sales ratio, dan price earnings ratio to growth (PEG Ratio).

\section{Hipotesis}

H1 : Current Ratio berpengaruh positif dan signifikan terhadap harga saham.

H2 : Return On Equity berpengaruh positif dan signifikan terhadap harga saham. 
H3 : Debt to Equity Ratio berpengaruh negatif dan signifikan terhadap harga saham.

H4 : Current Ratio, Return On Equity dan Debt to Equity Ratio secara simultan berpengaruh terhadap harga saham.

\section{METODE PENELITIAN}

\section{Populasi dan Sampel}

Populasi menurut Sugiyono (2017:80) adalah wilayah generalisasi yang terdiri atas obyek/subyek yang mempunyai kualitas dan karakteristik tertentu yang ditetapkan oleh peneliti untuk dipelajari dan kemudian ditarik kesimpulannya. Populasi yang digunakan dalam penelitian ini adalah seluruh perusahaan sektor kontruksi baik yang bangunan dan non bangunan yang terdaftar dalam Bursa Efek Indonesia. Populasi yang ada pada perusahaan kontruksi yang terdaftar di Bursa Efek Indonesia berjumlah 26 perusahaan yang didapat dari www.sahamok.com, sedangkan sampel menurut Sugiyono (2017:80) adalah bagian dari jumlah dan karakteristik yang dimiliki oleh populasi tersebut. Sampel yang digunakan dalam penelitian ini adalah perusahaan yang memiliki kelengkapan data keuangan pada tahun 2015-2017.

\section{Jenis Sumber Data}

Data yang digunakan dalam penelitian ini adalah data sekunder. Data sekunder menurut Azwar (1997:91) data sekunder adalah data yang diperoleh dari pihak lain, tidak langsung diperoleh oleh peneliti dari subjek penelitiannya. Data yang digunakan dalam penelitian ini adalah data yang diperoleh dari laporan keuangan tahunan periode 2015-2017. Laporan keuangan yang didapat dari www.finance.yahoo.com dan aplikasi FAST

\section{Teknik Pengumpulan Data}

Teknik pengumpulan data dalam penelitian ini adalah metode dokumentasi. Dokumentasi merupakan catatan peristiwa yang sudah berlalu, yang dapat berbentuk tulisan, gambar, atau karya-karya monumental dari seseorang (Sugiyono, 2016:326). Dokumentasi dari penelitian ini adalah data-data laporan keuangan perusahaan makanan dan minuman yang terdaftar di Bursa Efek Indonesia periode 2015-2017 yang dipublikasikan melalui situs Bursa Efek Indonesia (www.idx.co.id).

\section{Definisi Operasional}

\section{Varibel Dependen (Y)}

Variable dependen (variable terikat) sering digunakan sebagai variable output, kreteria, konsekuen. Merupakan variable yang dipengaruhi atau terjadi akibat, karena adanya varibel bebas (Sugiyono, 2016:64). Dalam penelitian ini yang menjadi varibel dependen adalah harga saham. Harga saham adalah nilai dari suatu saham yang diperjual belikan di Bursa Efek Indonesia yang diukur dengan nilai mata uang, harga saham tersebut ditentukan antara kekuatan demand dan supply.

\section{Variabel Independen $(\mathbf{X})$}

Variable independent (variable bebas sering disebut variable stimulus, predictor, antecedent. Merupakan variable yang mempengaruhi atau yang menjadi sebab perubahannya atau timbulnya varibel dependen (terikat) (Sugiyono, 2016:64). Variable independent yang digunakan dalam penelitian ini terdiri dari tiga variable diantaranya, yaitu:

\section{a. Current Ratio $\left(X_{1}\right)$}

Menurut Home (2005:206) rasio lancar adalah untuk menghitung kemampuan perusahaan dalam membayar kewajiban jangka pendek dengan aktiva lancar yang tersedia. Current ratio menunjukkan kemampuan perusahaan untuk melunasi kewajiban jangka 
pendeknya dari aktiva lancarnya. Rasio ini dihitung dengan membagi aktiva lancar dengan kewajiban jangka pendeknya. Likuiditas jangka pendek ini penting karena bisa mengakibatkan perusahaan bangkrut. Dalam melihat rasio lancar, analisi juga harus diperhatikan kondisi dan lingkungan perusahaan seperti rencana manajem, sektor indusri dan kondisi ekonomi makro secara umum (Darsono dan Ashari, 2005:53). Berikut ini formula untuk menghitung Current ratio $(C R)$ :

$$
\text { Rasio Lancar }=\frac{\text { Aktiva Lancar }}{\text { Utang Lancar }} \times 100 \%
$$

\section{b. Return on Asset $\left(X_{2}\right)$}

Return on Asset (ROA) merupakan bagian dari rasio profitabilitas dalam menganalisis laporan keuangan atas laporan kinerja keuangan perusahaan. Menurut Hanafi (2005:83) Return on Asset adalah rasio yang mengunkur kemampuan perusahaan menghasilkan laba dengan biaya-biaya untuk mendanai asset tersebut, ROA menunujukkan keefesienan perusahaan dalam mengelolah seluruh aktivinya untuk memperoleh pendapatan. Berikut ini formula untuk menghitung Return on Asset (ROA):

$$
R O A=\frac{\text { Laba Sebelum Pajak }}{\text { Aktiva }} \times 100 \%
$$

\section{c. Debt to Equty Ratio $\left(X_{3}\right)$} Menurut Darsono (2005:54), Debt to Equity Ratio adalah rasio yang menunjukkan presentase penyediaan dana oleh pemegang saham terhadap pemberi pinjaman. Semakin tinggi rasio, semakin rendah pendanaan perusahaan yang disediakan oleh pemegang saham. Dari prespektif kemampuan membayar kewajiban jangka Panjang, semakin rendah rasio akan semakin baik kemampuan perusahaan dalam membayar kewajiban jangka panjangnya. Berikut ini formula untuk menghitung Debt to Equity Ratio (DER):

$$
D E R=\frac{\text { Total Utang (Debt) }}{\text { Ekuitas (Equity) }}
$$

\section{Uji Instrumen}

\section{Statistik Deskriptif}

Statistik deskirptif adalah statistika yang digunakan untuk menganalisis data dengan cara mendeskripsikan data yang telah terkumpul tanpa bermaksud untuk membuat kesimpualan yang berlaku umum. Statistika deskriptif meliputi penyediaan data dalam bentuk tabel-tabel mengenai perhitungan mean, standar deviasi, nialia minimum dan maksimum.

Adapun persamaan regresi adalah sebagai berikut :

$Y_{i t}=\alpha+\beta 1 X 11_{i t}+\beta 2 X 2_{i t}+\beta 3 X 3_{i t}+e_{i t}$

Keterangan:

$\begin{array}{ll}\mathrm{Y} & \text { : Log Harga Saham } \\ \alpha & \text { : Konstanta } \\ \beta 1-\beta 3 & \text { : Koefisian Regresi } \\ \mathrm{X} 1 & : \text { Current Ratio } \\ (\mathrm{CR}) & \\ \mathrm{X} 2 & \text { Return On Asset } \\ (\text { ROA }) & \\ \mathrm{X} 3 & \text { Debt To Equity } \\ \text { Ratio }(\text { DER }) & \end{array}$

\section{a. Uji Normalitas}

Uji normalitas bertujuan untuk membuktikan bahwa data yang dipergunakan berdistribusi normal. Model regresi yang baik adalah distribusi data normal atau mendekati normal (Thoifah, 2015). Uji normalitas menggunakan uji Jarque-Bera dengan menggunakan bantuan progam statistik. Dasar pengambilan keputusan jika probibalitas lebih besar atau sama dengan nilai alpha yang ditentukan, yaitu 5\%, maka data dikatakan berdistribusi normal, dan sebaliknya jika probibalitas kurang 5\% maka data berdistribusi tidak normal. 


\section{b. Uji Autokorelasi}

Menurut Ghazali (2013:110) pengujian asumsi klasik dalam model regresi linier adalah uji autokorelasi bertujuan untuk menguji apakah dalam suatu model regresi linier ada korelasi antara kesalahan penganggu pada periode t-1 (sebelumnya). Jika terjadi korelasi maka terdapat problem autokorelasi.

Uji autokorelasi dapat dilihat dari

Durbin Waton. Apabila nilai DurbinWaston berada pada daerah dU sampai 4-dU kita dapta menyimpulkan bahwa model regresi tidak mengandung autokorelasi. Denga ketentuan sebagai berikkut:
a. $4-\mathrm{dl}<\mathrm{DW}<4$ mempunyai autokorelasi
b. 4-dU $<$ DW $<4-$ dl tidak ada kesimpulan
c. $\mathrm{dU}<\mathrm{DW}<4-\mathrm{dU}$ tidak ada autokorelasi
d. $\quad$ dL $<$ DW $<$ dU tidak ada kesimpulan
e. $0<\mathrm{DW}<\mathrm{dL}$ mempunyai autokorelasi positif

Uji B-G sering juga disebut sebagai uji LM (Lagrange Multiplier). Uji ini dapat menutupi kelemahan pada uji D-W ketika memberikan hasil "tidak ada kesimpulan" . Pengambilan keputusan dapat dilakukan sebagai berikut

Prob. Chi Square > 0,05 tidak ada autokorelasi

Prob. Chi Square $<0,05$ terjadi autokorelasi

\section{c. Uji Heteroskedastisitas}

Pengujian asumsi klasik yang keempat adalah uji heteroskedastisitas (heteriosccdasticity). Pengujian ini bertujuan untuk mengetahui ada tidaknya heteroskedastisitas, dalam hal ini akan dilakukan dengan menggunakan uji statistic, yaitu uji white, Uji ini menggunakan residual kuadrat variabel dependen dan independennya terdiri atas variabel independen yang sudah ada, ditambah dengan kuadrat variabel independen, ditambah dengan perkalian dua variabel independen. Pengambila keputusan dengan menggunakan program Eviews adalah sebagai berikut

Prob. chi square (p-value) $>0,05$ tidak terjadi heteroskedastisitas Prob. chi square ( $\mathrm{p}$ - value) $<0,05$ terjadi heteroskedastisitas.

\section{d. Uji Multikolinearitas}

Uji Multikolinearitas merupakan salah satu masalah dalam analisis regresi dengan OLS, yang berarti terdapat korelasi atau hubungan yang sangat tinggi diantara variabel variabel independen.

\section{Teknik Analisis Data}

Teknik analisis data yang digunakan dalam penelitian adalah analisis regresi data panel. Model analisis regresi data panel digunakan untuk mengolah data gabungan yang terdiri dari data silang (cross section) dan data runtut waktu (time series).

\section{Uji Chow}

Uji chow ini untuk menentukan apakah menggunakan metode common effect atau metode fixed effect, dengan pertimbangan:

Jika Prob. Chi square $<0,05$, maka fixed effect

Jika Prob. Chi Square > 0,05, maka common effect

Bila hasil menunjukkan common effect, maka penentuan model berhenti sampai disini. Akan tetapi, jika hasil menunjukkan model fixed effect, maka harus dilanjut dengan metode random effect dengan uji Hausman.

\section{Uji Hausman}

Uji Hausman digunakan apabila dalam Uji Chow menghasilkan metode random effect, sehingga harus diuji lagi untuk mengetahui hasilnya apakah metode fixed effect atau random effect. Pertimbangan uji Hausman adalah sebagai berikut :

Jika Prob. Cross section random $<0,05$, maka fixed effect 
Jika Prob. Cross section random > 0,05, maka random effect.

\section{Regresi Berganda}

Analisisis regresi linier berganda adalah hubungan antara dua atau lebih variabel dimana variabel independen yang mempengaruhi variabel dependen lebih dari satu (X1,X2,X3,,,,Xn). Dengan persamaan sebagai berikut.

$\mathrm{Y}=\beta 0+\beta 1 \mathrm{CR}+\beta 2 \mathrm{ROE}+\beta 3 \mathrm{DER}$

Dimana:

$\mathrm{Y}=$ Nilai Harga Saham

$\beta 0=$ Konstanta

$\beta 1=$ Koefisien Regresi X1

$\beta 2=$ Koefisien Regresi X2

$\beta 3=$ Koefisien Regresi X3

\section{Uji Parsial (T)}

Uji parsial (uji statistik T) digunakan untuk mengetahuipengaruh dari masing-masing variabel independen terhadap variabel dependen. Kriteria dalam uji $\mathrm{T}$ ini adalah sebagai berikut :

- Jika nilai koefisien menunjukkan positif, maka variabel independen berpengaruh positif terhadap variabel dependen.

- Jika nilai koefisien menunjukkan negatif, maka variabel independen berpengaruh negatif terhadap variabel dependen.

\section{Uji Simultan (f)}

Uji ini dilakukan yaitu untuk mengatahui variabel independen secara simultan berpengaruh terhadap variabel dependen. Uji ini dilakukan yaitu dengan sig $<\alpha(0,05)$ yang artinya menerima Ha atau dengan kata lain variabel independen berpengaruh secara simultan terhadap variabel dependen dan jika nilai sig $>\alpha$ $(0,05)$ maka artinya hipotesis ditolak yang artinya menerima $\mathrm{H} 0$.

\section{Uji Koefisien Determinasi (R2)}

Uji ini digunakan untuk mengukur seberapa jauh kemampuan model regresi dalam menjelaskan variasi variabel dependen (Ghozali, 2011). Nilai koefisien determinasi besarnya antara 0 (nol) dan 1 (satu). Apabila nilai R2 mendekati 0, maka kemampuan variabel independen dalam menjelaskan variabel dependen masih terbatas. Sebaliknya, jika nilai R2 mendekati 1, maka kemampuan variabel independen dalam menjelaskan variabel dependen cukup baik.

\section{HASIL PENELITIAN DAN PEMBAHASAN}

\section{Hasil Penelitian}

Statistik Deskriptif

Tabel 4.1

Statistik Deskriptif

\begin{tabular}{|l|c|c|c|c|}
\hline & HARGA_SAHAM & CR & ROE & DER \\
\hline Mean & 1805.313 & 1.479442 & 25.72864 & 2.825382 \\
\hline Median & 1435.000 & 1.400000 & 16.24000 & 1.865000 \\
\hline Maximum & 6425.000 & 3.140000 & 124.6100 & 14.14000 \\
\hline Minimum & 110.0000 & 0.320000 & -15.30000 & 0.390000 \\
\hline Std. Dev. & 1468.576 & 0.553015 & 28.11121 & 3.295941 \\
\hline
\end{tabular}

Berdasarkan tabel 4.1 dalam waktu 2015-2017 yang memiliki harga saham terendah yaitu pada tahun 2015 harga saham sebesar 110. Sedangkan harga saham tertinggi ada pada tahun 2017 sebesar 6425. Nilai current ratio terendah dalam waktu 2015-2017 ada pada tahun 2015 yaitu sebesar 0,32 . Sedangkan nilai tertinggi current ratio ada pada tahun 2015 yaitu sebesar 3,14.

Nilai return on equity terendah dalam waktu 2015-2017 ada pada tahun 2016 yaitu sebesar $-15,30$. Sedangkan nilai tertinggi return on equity ada pada tahun 2015 yaitu sebesar 124,61. Nilai debt to equity ratio terendah ada pada t ahun 2015 yaitu perusahaan Indonesia sebesar 0,39. Sedangkan nilai debt to equity ratio tertinggi ada pada tahun 2016 yaitu sebesar 14,14 . 
Uji Normalitas

Tabel 4.2

Data Normalitas

\begin{tabular}{|l|r|}
\hline Mean & $-1,03 \mathrm{E}-13$ \\
\hline Median & $-60,75777$ \\
\hline Maximum & 2366,965 \\
\hline Minimum & $-1757,471$ \\
\hline Std. Dev. & 1030,463 \\
\hline Skewness & 0,606891 \\
\hline Kurtosis & 2,639069 \\
\hline $\begin{array}{l}\text { Jarque- } \\
\text { Bera }\end{array}$ & 2,806187 \\
\hline Probability & 0,245835 \\
\hline
\end{tabular}

Sumber: Diolah dengan eviews 6

Berdasarkan tabel 4.2 diketahui nilai probability sebesar 0,245835 . Dimana nilai probability lebih besar dari alpha yaitu prob $(0,246)>\alpha(0,05)$ yang artinya data bersifat normal

\section{Uji Autokorelasi}

Tabel 4.3

Data Autokorelasi

\begin{tabular}{|l|r|l|r|}
\hline F-satistic & 2,484674 & Prob. F(2,36) & 0,0975 \\
\hline Obs *R-Squared & 5,09436 & Prob. Chi-Square (2) & 0,0783 \\
\hline
\end{tabular}

Sumber: Data diolah eviews 6 (2019)

Berdasarkan tabel 4.3, diketahui prob. Chi Square sebesar 0,0783. Nilai prob. Chi Square $0,0783>0,05$ yang artinya data tidak ada masalah autokorelasi.

\section{Uji Heteroskedasitas}

Data Heteroskedastisitas

\begin{tabular}{|l|c|l|l|}
\hline F-statistic & 1,877952 & Prob. F (9,32) & 0,0919 \\
\hline Obs *R-squared & 14,51622 & Prob. Chi-Square (9) & 0,1051 \\
\hline Scaled explained SS & 9,738441 & Prob. Chi-Square (9) & 0,3721 \\
\hline
\end{tabular}

Sumber: Data diolah eviews 6 (2019)

Penelitian ini menggunakan uji white. Berdasarkan tabel 4.4, diketahui prob (pvalue) sebesar 0,105 . Nilai $p$-value $(0,105)$ $>0,05$ yang artinya data tidak terjadi heteroskedastisitas.

\section{Uji Multikolineiritas}

Tabel 4.5

Data Multikolinearitas

\begin{tabular}{|c|c|c|c|}
\hline & CR & ROE & DER \\
\hline CR & 1.000000 & -0.257987 & -0.324092 \\
\hline ROE & -0.257987 & 1.000000 & 0.680839 \\
\hline DER & -0.324092 & 0.680839 & 1.000000 \\
\hline
\end{tabular}

Sumber: data diolah eviews 6 (2019)

Berdasarkan tabel 4.5, pengujian korelasi antara variabel independen tidak terlihat adanya gejala korelasi (derajat keeratan). Dimana derajat keeratan dinilai sangat tinggi jika nilai korelasi $(>0,90)$ antara variabel independen. Dalam data diatas terlihat nilai korelasi antara variabel $(<0,90)$ maka artinya data tidak menunjukkan adanya gejala multikolinearitas..

\section{Uji Regresi Data Panel}

Tabel 4.6

Uji pemilihan model data

\begin{tabular}{|l|l|l|}
\hline Uji & Indikator Uji & Keterangan \\
\hline Uji Chow & $\begin{array}{l}\text { Prob. Chi Square } \\
(0,0000)<0,05\end{array}$ & Metode terpilih \\
& Fixed Effects \\
\hline Uji Hausman & Prob $(0,0007)<$ & Metode terpilih \\
& 0,05 & Fixed Effets \\
\hline
\end{tabular}

Sumber: Data diolah eviews 6 (2019)

Berdasarkan data yang sudah diolah, baik menggunakan uji chow maupun uji Hausman sama-sama menunjukkan metode yang terpilih adalah fixed effects. Untuk itu metode yang digunakan dalam penelitian ini adalah metode fixed effects.

Tabel 4.7

Hasil Estimasi Model Pengaruh Current Ratio, Return On Equity dan Debt to Equity Ratio Terhadap Harga Saham

\begin{tabular}{|l|r|r|}
\hline \multicolumn{3}{|l|}{ Variabel Terikat= Harga saham } \\
\hline \multicolumn{1}{|c|}{ Variabel bebas } & \multicolumn{1}{c|}{ Koefisien } & Nilai Signifikansi \\
\hline C & 1149,220 & 0,0704 \\
\hline CR & 211,1798 & 0,5992 \\
\hline ROE & 25,01140 & 0,0008 \\
\hline DER & $-106,1256$ & 0,0218 \\
\hline R-squared & 0,944493 & \\
\hline Prob(F-statistic) & 0,000000 & \\
\hline obs & 42 & \\
Sumber: data diolah eviews 6 (2019)
\end{tabular}


$\mathrm{Y}=1149,220+211,1798 \mathrm{CR}$ +25,01140ROE - 106,1256DER

1. Y merupakan harga saham

2. 1149,220 merupakan konstanta. Yang artinya bahwa current ratio, return on equity dan debt to equity ratio konstan, maka rata-rata harga saham sebesar 1149,220 .

3. Koefisien regresi current ratio sebesar 211,1798 yang memiliki nilai positif. Artinya jika current ratio naik satu satuan maka harga saham akan naik sebesar 211,1798. Dan sebaliknya jika current ratio turun satu satuan maka harga saham akan turun sebesar 211,1798 .

4. Koefisien regresi return on equity sebesar 25,0114 yang memiliki nilai positif. Artinya jika return on equity naik satu satuan maka harga saham akan naik sebesar 25,01140. Begitu juga sebaliknya apabila return on equity turun satu satuan maka harga saham akan turun sebesar 211,1798.39

5. Koefisien regresi debt to equity ratio sebesar -106,125 yang memiliki nilai negatif. Artinya jika debt to equity ratio naik satu satuan maka harga saham akan turun sebesar 106,125. Namun apabila debt to equity ratio turun satu satuan maka harga saham akan naik sebesar 106,125

\section{Uji Parsial (T)}

Berdasarkan hasil pada tabel 4.7 maka dapat dijelaskan hipotesis mengenai masing-masing variabel:

\section{a. Current Ratio}

Uji t terhadap current ratio (X1) didapatkan nilai koefisien sebesar 211,1798 yang artinya current ratio mempunyai pengaruh positif terhadap harga saham. Current ratio memiliki nilai sig sebesar 0,5992. Dengan nilai alpha 0,05 maka didapatkan hasil $(0,5992>0,05)$ yaitu current ratio tidak berpengaruh terhadap harga saham. Dengan hasil tersebut yaitu hipotesis ditolak atau dengan kata lain menerima $\mathrm{H} 0$ yang artinya current ratio berpengaruh positif namun tidak signifikan terhadap harga saham.

b. Return On Equity

Uji t terhadap return on equity (X2) didapatkan nilai koefisien sebesar 25,01140 yang artinya return on equity mempunyai pengaruh positif terhadap harga saham. Return on equity memiliki nilai sig sebesar 0,0008. Dengan alpha 0,05 maka didapatkan hasil $(0,0008<0,005)$ yaitu return on equity berpengaruh terhadap harga saham. Dengan demikian hipotesis diterima yaitu return on equity berpengaruh positif dan signifikan terhadap harga saham.

\section{c. Debt to Equity Ratio}

Uji t terhadap debt to equity ratio didapatkan nilai koefisien sebesar 106,1256 yang artinya debt to equity ratio memiliki pengaruh negatif terhadap harga saham. Debt to equity ratio memiliki nilai sig sebesar 0,0218 . Dengan alpha 0,05 maka didapatkan hasil $(0,0218<0,05)$ yang artinya debt to equity ratio berpengaruh terhadap harga saham. Dengan demikian hipotesis diterima yaitu debt to equity ratio berpengaruh negatif dan signifikan terhadap harga saham.

\section{Uji Simultan (F)}

Berdasarkan tabel 4.7 didapatkan nilai sig sebesar 0,000. Dengan nilai alpha 0,05 maka didapatkan hasil $(0,000<0,05)$ yang artinya current ratio, return on equity, dan debt to equity ratio berpengaruh terhadap harga saham. Dengan hasil tersebut maka hipotesis yang diajukan diterima (Ha) yaitu current ratio, return on equity ratio dan debt to equity ratio secara simultan berpengaruh terhadap harga saham.

\section{Uji Koefisien Determinasi $\left(\mathbf{R}^{2)}\right.$}

Berdasarkan tabel 4.7 didapatkan hasil $\mathrm{R}$ square sebesar 0,944. Hal ini berarti $94,4 \%$ harga saham dipengaruhi 
oleh current ratio, return on equity dan debt to equity ratio sedangkan sisanya yaitu $5,6 \%$ harga saham dipengaruhi oleh variabel-variabel lain diluar dalam penelitian ini.

\section{Pembahasan \\ Current Ratio (X1)}

Berdasarkan tabel 4.7 didapatkan hasil bahwa current ratio memiliki nilai koefisien sebesar 211,1798 yang artinya current ratio memiliki hubungan positif dengan harga saham. Current ratio memiliki nilai sig sebesar 0,5992 dengan nilai alpha 0,05 maka didapatkan hasil $(0,5992>0,05)$ yaitu current ratio berpengaruh positif namun tidak signifikan terhadap harga saham. Hasil penelitian ini sejalan dengan penelitian Ferdianto (2014) yang menyatakan bahwa current ratio berpengaruh positif namun tidak signifikan terhadap harga saham.

Menurut Hanafi dan Halim (2005:79) Nilai rasio lancar pada perusahaan normal berkisar pada angka 2 . Rasio yang tinggi menunjukkan adanya kelebihan aktiva lancar sedangkan rasio yang rendah menunjukkan risiko likuiditas yang tinggi. Hasil yang tidak signifikan dalam penelitian ini dikarenakan nilai current ratio dalam data penelitian ini memiliki nilai kurang dari 2 yang ada pada beberapa perusahaan. Sehingga menyebabkan nilai current ratio tidak signifikan. Untuk itu hipotesis yang diajukan yaitu current ratio berpengaruh positif dan signifikan terhadap harga saham ditolak.

\section{Return On Equity (X2)}

Dalam tabel 4.7 memiliki koefisien sebesar 25,01140 yang artinya return on equity mempunyai pengaruh positif terhadap harga saham. Return on equity memiliki nilai sig sebesar 0,0008. Dengan alpha 0,05 maka didapatkan hasil $(0,0008<0,005)$ yaitu return on equity berpengaruh positif dan signifikan terhadap harga saham. Hasil penelitian ini sejalan dengan hasil penelitian Tan, Syarif dan Ariza (2014) yang menyatakan bahwa return on equity berpengaruh positif dan signifikan terhadap harga saham.

Return On Equity (ROE) adalah rasio yang digunakan untuk mengukur keberhasilan perusahaan dalam menghasilkan laba bagi para pemegang saham. Dengan adanya laba yang tinggi dalam suatu perusahaan akan menarik perusahaan investor dalam berinvestasi, karena jika laba tinggi menandakan bahwa perusahaan memiliki kinerja yang baik. Rasio ini memiliki pengaruh positif terhadap harga saham, yang artinya jika laba tinggi maka kinerja perusahaan akan baik yang berakibat harga saham pun akan naik. Sehingga semakin tinggi nilai rasio ini maka semakin tinggi harga saham begitu sebaliknya jika semakin rendah rasio ini maka harga saham pun akan semakin rendah. Dengan hasil yang signifikan menandakan bahwa investor yang akan menanamkan saham perlu memperhatikan nilai return on equity.

Berdasarkan hasil yang disampaikan maka return on equity berpengaruh positif dan signifikan. Dengan nilai koefisien yang positif menandakan setiap return on equity naik maka harga saham pun akan naik dan jika dilihat dari nilai sig, maka return on equity berpengaruh terhadap harga saham karena memiliki nilai sig < alpha. Untuk itu hipotesis yang diajukan diterima yaitu return on equity berpengaruh positif dan signifikan terhadap harga saham.

\section{Debt to Equity Ratio (X3)}

Pada tabel 4.7 didapatkan hasil debt to equity ratio memiliki nilai koefisien sebesar -106,1256 yang artinya debt to equity ratio memiliki pengaruh negatif terhadap harga saham. Debt to equity ratio memiliki nilai sig sebesar 0,0218. Dengan alpha 0,05 maka didapatkan hasil 
$(0,0218<0,05)$ yang artinya debt to equity ratio berpengaruh positif dan signifikan terhadap harga saham. Hasil penelitian ini sejalan dengan hasil penelitian Ratri (2015) yang menyatakan bahwa debt to equity ratio berpengaruh negatif terhadap harga saham.

Rasio ini menggambarkan seberapa besar hutang yang dimiliki perusahaan dibandingkan dengan jumlah modal sendiri yang dimiliki oleh perusahaan. Jika hutang yang dimiliki oleh suatu perusahaan lebih besar daripada modal yang dimiliki maka menandakan kinerja suatu perusahaan tersebut kurang baik yang berakibat pada turunnya harga saham karena kurangnya kepercayaan investor pada perusahaan tersebut yang disebabkan oleh kinerja perusahaan tersebut buruk. Nilai negatif yang didapat menandakan bahwa setiap nilai debt to equity ratio naik maka harga saham akan turun dan ketika nilai debt to equity ratio turun maka harga saham akan naik. Hasil yang signifikan menandakan bahwa investor yang akan menanamkan sahamnya perlu melihat nilai debt to equity ratio karena nilai debt to equity ratio berpengaruh terhadap harga saham.

Berdasarkan hasil yang disampaikan maka debt to equity ratio berpengaruh negatif dan signifikan terhadap harga saham. dengan nilai koefisien negatif menandakan bahwa setiap debt to equity ratio naik maka harga saham akan turun, dan jika debt to equity turun maka harga saham akan naik. Disamping nilai koefisien yang negatif, debt to equity ratio memiliki nilai sig<alpha yang menandakan bahwa debt to equity mempunyai pengaruh terhadap harga saham. untuk itu hipotesis yang diajukan yaitu debt to equity berpengaruh negatif dan signifikan terhadap harga saham diterima.

\section{KESIMPULAN DAN SARAN}

\section{Kesimpulan}

Berdasarkan hasil pengujian data dan hasil analisis statistik yang mengacu pada rumusan masalah dan tujuan penelitian tentang pengaruh current ratio, return on equity dan debt to equity ratio terhadap harga saham maka peneliti dapat membuat kesimpulan sebagai berikut:

1. Hipotesis 1 yang berbunyi current ratio berpengaruh positif dan signifikan terhadap harga saham dinyatakan dalam hasil penelitian ini adalah ditolak. Current ratio memiliki nilai koefisien positif namun memiliki nilai sig lebih besar dari pada alpha yang artinya current ratio tidak berpengaruh terhadap harga saham, sehingga hipotesis yang diajukan ditolak.

2. Hipotesis 2 yang berbunyi return on equity berpengaruh positif dan signifikan terhadap harga saham dinyatakan dalam hasil penelitian ini adalah diterima. Return on equity memiliki nilai koefisisen positif dan memiliki nilai sig lebih kecil daripada alpha yang artinya return on equity berpengaruh positif dan signifikan terhadap harga saham.

3. Hipotesis 3 yang berbunyi debt to equity ratio berpengaruh negatif dan signifikan terhadap harga saham dinyatakan dalam hasil penelitian ini adalah diterima. Debt to equity ratio memiliki nilai koefisien yang negatif dan memiliki nilai sig yang lebih kecil daripada alpha yang artinya debt to equity ratio berpengaruh positif dan signifikan terhadap harga saham.

4. Hipotesis 4 yang berbunyi current ratio, return on equity dan debt to equity ratio secara bersama (simultan) berpengaruh terhadap harga saham dinyatakan dalam 
hasil penelitian ini adalah diterima. Karena memiliki nilaisig yang lebih kecil daripada alpha maka artinya current ratio, return one quity dan debt to equity ratio secara simultan berperngaruh terhadap harga saham.

\section{Saran}

Dari hasil kesimpulan yang disampaikan maka peneliti ingin memberi saran sebagai berikut:

1. Bagi Penelitian Selanjutnya

Bagi penelitian selanjutnya lebih baik mencoba dengan menambah beberapa variabel lain dalam pengaruhnya terhadap harga saham dan menambah tahun penelitian agar hasil yang diteliti lebih optimal. Penelitian ini merupakan internal yang ada di suatu perusahaan maka peneliti lain dapat menambahkan faktor eksternal seperti kurs dan inflasi yang memungkinkan dapat mempengaruhi harga saham.

2. Bagi perusahaan

Bagi perusahaan sebaiknya lebih memperhatikan hutang dan modal yang didapat. Jika hutang yang ada pada perusahaan lebih besar dari modal maka akan berpengaruh pada beban perusahaan. Jika perusahaan memiliki beban yang besar maka itu akan mempengaruhi minat investor dalam menanamkan sahamnya dan akan berpengaruh terhadap harga saham. Selain hutang dan modal, perusahaan perlu memperhatikan laba bersih karena laba bersih merupakan salah satu acuan yang digunakan investor dalam menanamkan dana ke suatu perusahaan. Dengan laba bersih investor dapat menilai kinerja yang ada di suatu perusahaan baik atau tidak.

3. Bagi Investor dan Calon Investor

Bagi investor dan calon investor sebaiknya perlu memperhatikan variabel lain diluar penelirtian ini agar lebih meyakinkan suatu perusahaan memiliki kinerja yang baik atau tidak yang nantinya akan mempengaruhi harga saham.

\section{DAFTAR PUSTAKA}

Azwar, Saifuddin. 2016. Metode Penelitian. Yogyakarta: Pustaka Pelajar. Darmadji, Tjiptono, dan Hendy M. Fakhruddin. 2011. Pasar Modal di Indonesia. Jakarta: Salemba Empat.

Eduardus, Tandeliin. 2007. Analisis Investasi dan Manajemen Portofolio. Yogyakarta: BPFE Fahmi, Irham 2009. Teori Portofolio danAnalisis Investasi Teori dan Soal Jawab. Yogyakarta: ALFABETA.

Ferdianto, E. 2014. Analisis Pengaruh Return On Asset (ROA), Debt to Equity Ratio (DER), Net Profit Margin (NPM) dan Current Ratio (CR) Terhadap

Harga Saham: Studi Empiris Pada Perusahaan Tambang yang Terdaftar di Bursa Efek Indonesia Tahun 2011-2013. Skripsi. Jakarta: Universitas Islam Negeri Syarif Hidayatullah.

Gunawan, Hendra, 2018, 2018 Saham Sektor Konstruksi Mendapat Angin Segar. Didapatkan: <http://www.tribunnews.com/bisnis/ 2018/01/29/2018-sahamsektorkonstruksi-mendapat-angin-segar [29>Januari 2018].

Halim, Abdul. 2005. Dasar-dasar Teori Portofolio dan Analisis Sekuritas. Jakarta: Salemba Empat.

Hanafi, Mamduh M, dan Abdul Halim. 2005. Analisis Laporan Keuangan. Yogyakarta: UUP AMP YKPN.

Hartono, Jogiyanto. 2007. Teori Portofolio dan Aanalisis Investasi. Yogyakarta: BPFE. 
Husnan, Suad. 1998. Manajemen Keuangan Teori dan Penerapan (Keputusan Jangka Pendek. Yogyakarta: BPFE.

Khairani, R. 2017. Pengaruh Current Ratio, Return On Assets (ROA), Dan Debt To Equity Ratio (DER) Terhadap Underpricing Saham Pada Saat Initial Public Offering (IPO) di Bursa Efek Indonesia (BEI). Skripsi. Medan: Universitas Negeri Islam Sumatera Utara).

Kusuma, Desta Rizky, dan Deny Ismanto. 2012. Modul Praktikum Eviews. Yogyakarta: Universitas Ahmad Dahlan 